\title{
Katarzyna Turonek-Ostrowska
}

\section{HIGHER EDUCATION OF WOMEN AT THE TSARIST UNIVERSITY OF WARSAW*}

В статье анализируется процесс получения женщинами высшего образования в Императорском Варшавском университете в 1869 1915 гг. Рассматриваются способы неформального женского образования в 1880 -е гг. в Варшаве (так называемый Летучий университет и др.) на фоне роста общественного сознания и спроса на профессиональное образование женщин и признание их профессиональной деятельности. В 1908 г. при Варшавском университете были созданы Высшие женские курсы (по аналогии с Бестужевскими курсами в С.-Петербурге), включавшие в себя три факультета: историко-филологический, физико-математический и правовой. Административный центр курсов располагался в здании Варшавского университета. Высшие женские курсы использовали часть университетской программы, среди преподавателей были профессора Варшавского университета. Курсы находились под строгим контролем государства и должны были конкурировать с другими частными курсами, по этой причине программа обучения была довольно разнообразна и привлекательна. Она включала в себя научно-исследовательские экспедиции с целью изучения гуманитарных и естественных наук. В статье основное внимание уделяется рассмотрению структуры обучения на историкофилологическом факультете с акцентом на программе по философским предметам.

Ключевые слова: высшие женские курсы, высшее образование для женщин, преподавание философии, Варшавский университет.
The article provides an analysis of the process of obtaining higher education by women at the Tsarist University of Warsaw in 1869-1915. The non-formal ways of getting female education in the 1880s in Warsaw (the so-called Flying University, etc.) are considered against the background of growing public awareness and demand for women's vocational education and recognition of their professional activities. In 1908, the Higher Women's Courses were organized at the University of Warsaw (by analogy with the Bestuzhev courses in St. Petersburg), which included three faculties: historical and philological, physical, mathematical, and legal. The administrative center of the courses was located in the building of the University of Warsaw. The educational program of the Higher Women's Courses was partly based on the university program, among the lecturers there were professors of the University of Warsaw. The courses were under strict state control and were supposed to compete with other private courses, for this reason the curriculum was quite diverse and attractive. It included research expeditions to improve studying the humanities and natural sciences. In 1911, an expedition was organized to St. Petersburg, and in 1913 to the city of Dombrov-Gurnich. The article focuses on the study of the education structure at the Faculty of History and Philology with an emphasis on the philosophical subjects program.

Keywords: Higher Women's courses, higher education for women, teaching philosophy, University of Warsaw.

\footnotetext{
* The text was created as a result of work on a project financed by National Science Centre of Poland: "Invisible: Women in Russian Philosophy", according to the agreement (UMO-2017/25/B/HS1/00530).
} 
In this article, I would like to present the ways women could get higher education at the Tsarist University of Warsaw (1869-1915). First of all, I will focus on discussing the structure of the Higher Female Courses. In the eighties of the nineteenth century in Warsaw, women were educating informally in the so-called Flying University. They could also receive education at home, in schools, at courses for girls, but the walls of the universities were closed to them. Only wealthier girls could afford to taking up studies abroad because it was associated with higher costs of living than staying in the country. One of such universities was the University of Bern, in Switzerland, where foreigners could study philosophy, medicine, law and theology. Since 1870, women began to study there.

The Tsarist University of Warsaw was founded in 1869, it had never opened its auditoriums to women, it survived to July 7, 1915. Following the history of emancipatory movements, we learn that earlier higher education for women was one of the postulates of the women's movement in the Kingdom of Poland. Despite the fact that some people considered as an absurd the aspirations of women to university education, within the circles of the Warsaw intelligence there was born the idea of establishing a university for women [13, p. 737]. Eliza Orzeszko also took her voice: "Not in the name of incorrect feminine emancipation, not in the name of the false wisdom, which takes away its proper charm and detaches it from useful and obligatory work, but in the name of family peace and the power of the family idea, in the name of human dignity, which the strongest support is education and work, in the name of the unclaimed right of every human being to participate in happiness from the flowing light, one must cry for Women's education" [16, p. 155; 6, p. 90]. The writer thought that it was not a priority issue if the University of Warsaw would allow a woman to study or open a new institution. Higher education for women had to prepare them effectively for the profession, be democratic, free and on an equal level as men's education [13, p. 775]. It is also known that in 1883 , one of the donors donated 20,000 silver rubles for the use of a university for women in Warsaw [5, p. 309]. The sum of the money was not enough for the establishment of the institution, and the disputes that arose around the donation, and trips abroad of potential female candidates for students, determined about the fall of this initiative [13, p. 775]. This is what was written about this issue in "The Literary Feast" (1883): "A university for women is not, however, abnormal or ridiculous, yes, every science is a benefaction, a university cathedral for women not only in the capital would be desirable, but even in any other larger city, because there are everywhere intelligences and special dispositions that desire learning in its entire area. We consider it as a waste of time to 
debate whether university would be useful for us - after all, even an Eastern languages cathedral would not be unnecessary if we could only give a penny disposing of the necessary needs and the needs already satisfied. The University will not demoralize, will not detract the woman from the duties of wife and mother, will not dematerialize society, it will only facilitate learning to those, who seeking for light blindfold waste a lot of body and spirit forces, a lot of time, so they waste a lot of short life. The same purpose has the university for male youth - it is a rendezvous of professors with students, but nobody walks away from this rendezvous as a wise man, he must get the title on his own, by building it on what the school has given to him" [5, p. 309]. In the same issue of the magazine, we read a letter from one of the readers who supported the founding of the female university in Warsaw, at the beginning she wrote about the emancipation of women: "What has she should passed, what accusations she had on her, what ridiculousness and contempt she was covered - we all know about it well. However, she gained a position, today everyone understands that a woman as a human being can be an independent being... Let us act, let us get, so that this emancipation will bear fruit at us, but not like the current unprofitable and ridiculous... Let us give them a university here, where among themselves, among the family tradition of respectable customs, they would get for themselves a bite of bread, without exposing themselves to the loss of virtues, until now our virgins adorning" [1, p. 310]. Women have come a long way to be able to educate, to get professions and to displace from the public opinion that the education on a higher level is not necessary for them, and moreover, they showed that it can bring a lot of good for both genders. Probably public opinion was caused by the fact that mainly male representatives were afraid of changes that will come after the admission of women to higher education, it could also result from the patriarchal family model, in which a man was the head of the family, worked professionally, and a woman dealt with household work and bringing up children. Sometimes even Ladies thought that education for women are unnecessary. This opinion was expressed mainly by wealthy women who led a comfortable life, they also had the opportunity to take basic education at home, which was learning of foreign languages, playing instruments, and the profession they could prepare for is usually a home teacher (governess). Joanna Dobkowska writes that there began to criticize the so-called "salon education", typical for the higher classes of society. As a part of it, girls were taught mainly good manners, calligraphy, needle works, skills called "womanlike" and the so-called talents were expanded - the ladies practiced playing the instrument (usually on the piano), often drawing or/and singing. The main emphasis, however, was on learn- 
ing languages, especially French. His knowledge in the common sense was the basis of women's education. Prepared in this way, the lady could easily find herself in the living room and find her husband with equal ease [6, p. 90]. Fortunately for the fair sex, the situation of women's education began to change and their opinion on this topic also, because their awareness increased, that education is a good in itself. Jolanta Kolbuszewska writes: "For the sake of self-education and complementing knowledge by ladies, there were created in larger cities (including Warsaw, Poznan, Krakow or Lvov) secret and open Science Living Rooms, in which library collections were made available to women" [11, p. 37]. It is worth mentioning here that since 1896, there have been operating commercial schools in Warsaw, separately for women and men. We quote Jyzef Miąso: “These were the schools of Edward Rontaler F. Laskus, the female trade courses of Izabella Smolikowska and Jyzefa Siemiradzka and Siemiradzka female trading classes... Listeners of female courses were usually daughters of free profession representatives, especially doctors, architects, lawyers, etc., who have already completed pensions or middle schools and wanted to gain professional qualifications" [15, p. 148]. The interest in the schools of a commercial nature resulted from the public demand for professionals and from the general situation of the Ministry of Education. Włodzimierz Wakar in 1915 in the Public Education in the Kingdom of Poland in 1905-1915, writes: "In 1906/7 there were 7 women's schools in the Kingdom of Poland (1243 schoolgirls), in 1912/13 their number increased to 17 , and school-girls - up to 3540" [14, p. 162]. At Josepha Siemiradzki courses there were only educating graduates of secondary schools. In 1908, they were transformed into three years and took the name of Female Higher Trade Courses of Jyzefa Siemiradzka. For these courses there was a payment of 150 rubles a year, for such education there could afford only wealthier girls, because it was a considerable sum of money. In the years 1897-1910, 326 girls graduated them. As many as 224 graduates took up a job in trade, " 12 were employed in education, 16 continued to study in foreign universities, and 78 did not work at all" [14, p. 162]. Awareness and demand of the society grew when it comes to women's admission to professional job and directional education. In the $19^{\text {th }}$ century Briton Henry Thomas Buclke (1821-1862) in "The Influence of Women on the Progress of Knowledge" expressed the opinion that the claim that higher education of women is not necessary, hurt them very much. He argued it, among others by the fact that many geniuses had wonderful mothers who deprived their sons of coldness and roughness [14, p. 42]. In the years 1882-1883 in Warsaw, in private homes there were being carried out secret self-educational courses for women, which in 1885 
were transformed into a higher school, so-called "The Flying University", also called "The Women's University", due to the large percentage of studying there women. Men also studied there, but due to the fact that they had other options and did not have to take secret learning, there were far fewer of them. Secret learning was possible at three faculties: Social Sciences, History and Philology, which also included pedagogy, and Mathematics and Natural Sciences. Students had the opportunity to listen to lectures, among others historians, such as: Władysław Smoleński and Tadeusz Korzon, men of letters: Bronisław Chlebowski, Ignacy Chrzanowski and Piotr Chmielowski and philosopher Adam Mahrburg (1855-1913). Years later, "The Flying University" was transformed into a legally operating "Scientific Courses Society" [15, p. 63-65].

Due to the interest of women in higher education, in 1908 at the University of Warsaw, there were created Higher Female Courses. In the $19^{\text {th }}$ century, such courses existed already in St. Petersburg, the so-called Bestuzhevskie Courses ${ }^{1}$, attracted a lot of interest. The Warsaw Courses were created by professors and lecturers of the Warsaw University as a private institution, therefore they did not receive government subsidies, and the financial basis was tuition fees. According to Artur Markowski, "the authorities of the Warsaw University did not conceal that the purpose of establishing courses is to increase the number of working hours and higher salaries. It does not change the fact that women could formally take education. At the courses there studied Polish and Russian students, they studied humanistic, pedagogical and medical subjects" [13, p. 736-738]. The courses were held in the building of the Warsaw University, from which, with the permission of the Ministry of Education, women benefited for free of charge, in the afternoon hours, free from the classes. They had to pay for the use of light and fuel, and obtained

${ }^{1}$ The Bestuzhevskie Courses were created in 1878 from the initiative of Anna Filosofova (1837-1912), a Russian philanthropist and activist for the rights of women to education. The official founder of the courses was the historian Konstanty Bestużew-Ruimin (1829-1897). The courses in St. Petersburg had the following faculties: literaryhistorical, physical-mathematical and mathematical specialist, and from 1906 also legal. The courses were slightly financed by the government, but were supported by society. In 1886, they were suspended and their activity resumed in 1889 and they functioned until 1917. There was also established The Society for the Assistance of Higher Female Courses. The aim of the Society was to collect funds. The members of the Society may have been adults and those who were not in active service. All the funds, The Society collected from membership fees, from voluntary donations, from money collected during specially organized lectures, concerts and performances. Next, there were set scholarships for Higher Female Courses and the authorities of the courses distributed these scholarships between the participants. 
the necessary training materials. Statute of the courses was approved by the Curator of the Warsaw Scientific District on September 4, 1909, which they were directly subjected to and confirmed by the Ministry of Education [17]. The internal authorities, were: a director, a Council composed of lecturers and a Management composed of a director as a chairman and deans of individual faculties. The course program indicates that they were divided into three faculties: Historical-Philological, Physical-Mathematical and Legal [20]. The director was the law professor Ivan Nikolaevich Trepicyn ${ }^{2}$ (in the years 1910-1913 the Rector of the Warsaw University), who was elected by the Council from lecturers holding the title of professor of higher education. At the Higher Female Courses, there were used some university courses of study the some of the professors were staff from the Warsaw University. The lecturers were drafted from among persons holding the academic degree of the Russian university or the right to lecture in higher schools in Russia [17].

As I mentioned, courses for women were divided into three faculties. At the Historical-Philological Faculty ladies studied the following subjects: Comparative Linguistics and Sanskrit; Classical Philology; Slavic-Russian Philology; Romano-German Philology; History of Art; Political Economy and Statistics; General History; History of Russia; Philosophy (Psychology, Logic, Aesthetics, History of Philosophy); Pedagogy and Methodology of Studying different disciplines; Modern Languages.

${ }^{2}$ Trepitsyn Ivan Nikolaevich (1868-?), a Russian lawyer. He graduated from the Faculty of Law at the University of St. Vladimir in Kiev, then he worked as a law lecturer in Novorossiysk. From 1900, he was on a foreign academic practice. From autumn 1902, he worked at the University of Warsaw as a lecturer in civil, constitutional and material law. In 1904 he became a professor, and in 1910 he became dean of the Faculty of Law. In 1910 he became the rector of the university. After leaving Warsaw in 1915, he accepted a post at the Ministry of Justice in St. Petersburg. Until 1917 he lectured on Roman law at the University of St. Petersburg. His further fate is unknown [8, p. 125130]. In the Archival Materials of Ivan Nikolaevich Trepitsyn at the Tsarist University of Warsaw (No. 72/214/663-664) there are documents regarding his work as the Rector of the University of Warsaw, general documents and ordinances of the rector. To date, no photograph has been found showing the image of Professor I. N. Trepitsyn. 
Philosophical disciplines were taught by Professors E. A. Bobrov ${ }^{3}$ and V. A. Flyaksberger ${ }^{4}$. They lectured psychology, logic, aesthetics and the history of philosophy. In addition to the texts of great philosophers, students studied the research papers of professor Bobrov regarding Aristotle's logic or art [2, p. 3]. They also read the works of Baruch Spinoza, John Locke, George Berkeley, David Hume, Gottfried Leibniz, Immanuel Kant, Johann Fichte, Wilhelm Schelling, Georg Hegel, Friedrich Schleiermacher, Franz von Baader, Arthur Schopenhauer, Friedrich Nietzsche, Augste Comte, Herbert Spencer, Wilhelm Wundt [2, p. 18-21].

The program of philosophical subjects of the Female Courses was equalized with the university programs and included history of philosophy, methodology and theory of knowledge. Lecturers accentuated that philosophy is an unifying factor in the system of education, showing similarities and differences between different ways of its practice. Participants of courses had to know main assumptions of philosophical classics, the most important notions in philosophy, connections between ancient and modern philosophy, the most important textbooks about history of philosophy, main rules of academic education and position that philosophy had on this subject-matter. It shows that teaching philosophy on the Female Courses was on the highest level. This very interesting program of higher education is a testament of ability of female participants to gain knowledge and professors' serious approach to teach those of female sex [2, p. 17].

According to the report in the archives in St. Petersburg, at the Historical-Philological Faculty, 39 women completed the full teach-

${ }^{3}$ Bobrov Evgeniy Aleksandrovich (1867-1933), a Russian philosopher, graduated from the St. Jerzy University in 1895, he defended his master's thesis of philosophy "The relation of art to science and morality". In the thesis, Bobrov expressed his views, which he developed under the influence of Teichmuller's philosophy. He was a professor of philosophy at the Kazan University, then at the Warsaw University. In addition to giving lectures at the Higher Female Courses, he led the Pedagogical Circle of Students at the Tsar University of Warsaw. His more important works are "From the History of Critical Individualism" (Kazan, 1898), "Literature and Enlightenment in the 19 century Russia. Materials, research and notes" (Kazan, 1900-1903), "Philosophy in Russia. Materials, research and notes" (Kazan, 1899-1903). See [3].

4 Flyaksberger Vladimir Andreyevich (1876-?, probably 1914), a Russian philosopher specializing in the philosophy of Immanuel Kant, associate professor at the St. Petersburg University Philosophy Faculty of (1908-1910) headed by Alekandr Vvedensky. He worked at the Warsaw University in the years of 1911-1912, also taught pedagogy and philosophy at the Higher Female Courses in Warsaw. His more important works are "Teaching of Kant in the Field of Mathematics" (Warsaw, 1901), "Materials For the History of Epistemology" (Warsaw, 1914). See [7]. 
ing course and they received the final certificates ${ }^{5}$. From the schedule of classes for the II semester of 1912-1913 at the Higher Warsaw Female Courses at the Historical-Philological Faculty, we find out that Latin, Greek and French languages were taught [19]. Undoubtedly, ancient languages gave students the opportunity to broaden understanding of the ancient wise men's texts. The Greek language was taught by Aleksandr Martynowich Pridik (1864-1936) ${ }^{6}$, one of the authors of the first Russian encyclopedia, "Brockhaus and Efron encyclopedic dictionary". Latin and classical literature of the Romans were taught by the historian P. N. Chernyaev ${ }^{7}$ specializing in studying ancient times.

5 The report was made available to me by Professor Nadezhda Orlova, who was working on reports on the implementation of the Higher Female Courses in St. Petersburg. She was analyzing them by implementing a project funded by National Science Centre of Poland: "Invisible: Women in Russian Philosophy", according to the agreement (UMO-2017/25/B/HS1/00530). The report lists the students who completed the following courses: Alper Matylda, Bojdynska (nee Sitkevicz) Ludmila, Chmychova Olga (nee Zirnova), Donchin Lidia, Direktorovich Liba, Fyodorova Antonina, Fyodorova Julia, Firenkranz Maria, Gamerlinska Maria, Gavrilova (nee Jaskiewich) Maria, Golubkina Maria, Grajeva Malka, Gorska Zinaida (nee Gurieva), Hozaeva Mariam, Julia Fedorova, Kaufmann Roksa-Leja, Kipe Janina Marina, Krwioszejna Irena, Landina Helena, Leczevska Maria (nee Kaffka), Listovska Anna (nee Jaskiewich), Makarova Katarzhyna (nee Etel), Michalovska Ljubov, Moisejeva Aleksandra, Narbut Maria (nee Dzevchupolska), Niedymova Maria, Potyomkina Sofia, Potyomkina Maria, Rubinova Evgenia, Rukan Neonila (nee Podolska), Ruban Anna, Szegrynia Nadezhda, Spiridon Olga, Trejwich Sara, Wilderman (nee Szereszewo) Zofia, Jasinska Vera, Jasinska Galina (nee Beloglodzka), Zelman Dajcha (nee Dasza), Zdanova Olga, Zubatova Olga [2, p. 8].

${ }^{6}$ Pridik Aleksandr Martynowich (1864-1936) in the years 1882-1887 studied at the Dorpat University, then he continued his studies at the Berlin University. In 1889 he returned to Dorpat and received the rank of ancient classical philology candidate, three years later he delivered lectures as a private associate professor of classical philology at the Dorpat University. In 1902 he defended his doctoral thesis "Isaiah's sixth speech. Research in the field of ancient genealogy and ancient civil law". In 1904 he became an associate professor at the Tsar University of Warsaw at the Department of Greek Literature, moved to Warsaw where he lived and worked until 1915. Then he taught at the Rostov-on-Don University, later he moved to Dorpat, where he taught ancient history and art history until 1921. He wrote many reviews and articles [9, p. 118-124].

7 Chernyaev Pavel Nikolaevich (1863-1931) graduated from high school in Kazan in 1882, then he studied at the historical-philological department at the Kazan University and remained at the university to prepare for the professorship. After graduating from school, Chernyaev became a teacher in the Kazan Grammar School, later he was a school's director in Saratov. Since 1909, he delivered lectures at the Warsaw University, then in Rostov-on-Don, where he worked until retirement. He specialized in classical history and literature. His works are dealt with the Roman history, everyday life and culture of Romans. The most important works are "Hunger in the Classical World" (Kazan, 
The following subjects were lectured at the Physical-Mathematical Faculty: Classical Mathematics; Theoretical Mechanics; Astronomy and Geodesy; Physics; Chemistry; Mineralogy; Geology and Paleontology; Botany; Zoology, Comparative Anatomy and Physiology; Geography; Hygiene; Agronomy.

At the Legal Department there were the following courses: Law Encyclopedia History of Law Philosophy; Political Economy and Statistics; Comparative History of Law; History of the Slavic Nations Law; History of Russian Law; Roman Law; State, Russian and Foreign Law; Administrative Law; Criminal Law and Criminal Proceedings; Financial Law; Civil Law and Civil Proceedings; Financial Law and Commercial Proceedings; Church Law; International Law [18].

In 1911, at the Legal Department there was established the Commercial Department, approved by the Curator of the Scientific Circle, where there were taught the following subjects: General and Specialist Accounting; Commercial Arithmetic; General and Special Commodity Research; Russian and Foreign Commercial Correspondence; Economics and History of Trade and Applied Economics; Economic Geography; Money Circulation and Banks; Modern Languages; Legal Subjects; History of Roman Civil Law; Trade and Competitive Legal Proceedings; Work and Factory Legislation [17].

In 1909 , over 500 women of different nationalities and confessions took part in the classes. Ladies learned humanistic, pedagogical and medical subjects. Researchers think that it is difficult to determine the specific interests of the student's courses. It can be observed that Jewish women were more likely to choose mathematicalphysical subjects, women of the Orthodox faith - philological. The courses were under strict state control and were to compete with other private initiatives. Therefore, there was sought a varied and encouraging course of study. There were scientific expeditions connected with the humanities and natural sciences in the program: in 1911 to St. Petersburg, and in 1913 to Dabrowa Gornicza. Departures took place with the assistance of the University researchers.

Warsaw's Higher Female Courses had their first graduates in the academic year 1912-1913 and that circumstance coincided with the rights of female education act coming into force on December 19, 1911. The act was titled "On the examination of females in the knowledge of the course of educational institutions and on the procedures for obtaining by them degrees and academic titles" [11, p. 205]. It brought about the situation that listeners of Higher Female Courses could, after finishing studies, directly take final exams

1899), "Observations on the Ancient Roman Comedy. About the History of Types" (Kazan, 1905), a textbook for teachers on the methodology of Latin language teaching [4]. 
at national commissions. In this time-period, to get a diploma of university degree, you had to pass final exams. Only on March 28, 1913 Minister's of Education decree came into force and equalized every private Higher Female Courses with national courses [2, p. 1]. In the report about Warsaw's Higher Female Courses there is an entry that the existence of higher education for women is needed and beneficial, because it furthers the development of science [2, p. 2].

On September 21, 1915, the Tsarist University of Warsaw together with the documentation was transferred to Rostov-on-Don. The Higher Female Courses with the consent of the Ministry of Education moved there too. They were very popular because "they were the only ones in which girls could get a higher education in a prestigious educational institution, so all those who wanted to learn, wanted to be here" [12, p. 195-196]. At the end of September 1915, the school district assignee in Warsaw informed the administration of the courses that the Ministry of Education had agreed to transfer the courses to Rostov-on-Don. Until 1916, there was elaborated a bill on Higher Female Courses, in which it was written that "Higher Courses for Women are educational institutions. They aim to provide women with university-level academic education and to diffuse scientific knowledge. Courses for women in higher society level are the autonomous institution managed under statutes and independently organizing their scientific, educational and administrative activities" [12, p. 196]. Yet in November 1915, a meeting of public figures, lawyers, journalists and university professors took place in November to develop the statute of courses. The director of the Higher Female Courses in Rostov became professor of law Fedor Fedorovich Zigel (1845-1921), who during the meeting indicated that the existence of Courses in Warsaw was justified and should be continued in Rostov-on-Don. His speech was received positively [22].

In the case of vacancies, after the admission of women, the opportunity to study was also given to men who met the educational requirements for admission to the university. To enroll in the Higher Courses for Women at the University of Rostov it was necessary to submit an application to the course director from June 1 to September 1 . The examination of applications and the announcement of the lists took place on 1 September. An applicant had to indicate a faculty, submit a certificate of completion of seven grades for a girls' school or a certificate of seven classes of diocesan schools in other educational institutions. Students who moved from other higher education institutions had to submit an attestation or certificate indicating the time before participation in higher education. Most of the candidates had a certificate of graduation from the grammar school of the Warsaw district, or a certificate of completion of an 
educational institution in the Kingdom of Poland. The final exams lasted from December 1 to February 1. The commission usually held three meetings, and at the first of them there were considered and approved the programs, at the second - here were discussed some issues related to research and ultimately - there were analyzed the results of research and awarded diplomas [12, p. 195]. Many teachers and students of the Higher Female Courses organized additional classes. From 1917, at the History and Philology of Higher Female Courses there was established the Culture and History Circle. Members of the Circle gathered literature, visited museums, art galleries. During the meetings, they discussed topics concerning the history of culture. In 1920, the Higher Female Courses were combined with the University in Rostov-on-Don [12, p. 196-198].

The evacuation to Rostov-on-Don did not close the possibility of participating in this type of education in Poland. At the University of Warsaw, there was also the Institute of Obstetrics, located in the building of the Infant Jesus Hospital, where young women learned at obstetrics courses. "To the midwifery school, there were assumed only healthy women, 'without any repugnant defect, having good eyesight and hearing' having slim hands, able to read and write. It was also recommended for them to be strong and clean, 'they should not have stinking breath, no rashes on the body, and even more malignant ulcerations: e.g. of scabies and venereal type'. In addition, they had to: be conscientious, courageous, persistent, modest, taciturn, able to keep secret, selfless, avoid alcohol, be of a good reputation in the environment from which they came. There were also some age requirements for midwifery candidates. Ideally, when they were people between 18 and 30 years old, 'because older women find learning harder and are not so much eager for giving services that is required from the midwife, they can briefly practice their profession"" [21, p. 85-99]. The Institute of Maternity had of great social importance, yet it did not attract public attention. The press systematically gave the number of students at the University, sometimes the number of students of the Surgeon's Courses, but there were very rarely mentioned the number of future midwives. I agree with Artur Markowski that pharmaceutical courses for women also played an important role. The authorities of the Warsaw University did not agree that women would pass the commission exams, which enabled them to find a job in the profession [13, p. 736-738]. Without a proper diploma, ladies could not apply for a better job, that is why a significant part of them went to cities where it was possible to take the exam.

After the withdrawal of Russian troops from Polish territories in August 1915, the Warsaw University was reopened in November of 
the same year and then for the first time there were allowed women to study, ladies mainly studied at the Faculty of Philosophy, Pedagogy and Medicine.

\section{References}

1. Anonymous, Mr. editor!, in The Literary Feast, 1883, no. 385.

2. Archival materials in St. Petersburg, Reports about the Higher Female Courses in Warsaw, 3A 1912-1913, Warsaw, 1914.

3. Bobrov Yevgeny Aleksandrovich, in Nauka. Iskusstvo. Velichiye. Biograficheskiy slovar' (2000 g.) [Science. Art. Greatness. Biographical Dictionary (2000)], URL: biografii.niv.ru/doc/dictionary/biographical/fc/slovar-193-15.htm.

4. Chernyaev Pavel Nikolaevich, in Soyuz zhurnalistov Rossii. Saratovskoye otdeleniye [Union of Journalists of Russia. Saratov Branch], URL: sarunion.ru/actual/letopis/ 1706-chernyaev-pavel-nikolaevich.html.

5. Confusion of opinion (University for women in Warsaw), in The Literary Feast, 1883 , no. 385 .

6. Dobkowska, J., Views on the need and scope of education of women prevailing in the second half of the 19 and at the turn of the 19 and 20 centuries, in Acta Universitatis Lodziensis, Folia Historica 96, Lodz, 2016.

7. Flyaksberger Vladimir Andreyevich, in Nauchnoye naslediye Rossii [Scientific heritage of Russia], URL: library.ruslan.cc/authors/фляксбергер-владимир-андреевич.

8. Gawkowski, R., Ivan Nikolajewich Trepitsyn. Rector in the years 1910-1913, in Rector of the University of Warsaw, Monumenta universitatis varsoviensis 18162016, Warsaw, 2016.

9. Kazarov, S.S., Professor Aleksandr Martynovich Pridik v Varshave (1904-1915) [Professor Alexander Martynovich Pridik in Warsaw (1904-1915)], in Rossiyskopol'skiy istoricheskiy al'manakh [Russian-Polish Historical Almanac], no. 8, Stavropol, 2016.

10. Kolbuszewska, J., Polish women at universities - difficult beginnings, in Sensus Hirtoriae, 2017, no. 26.

11. Kosetchenkova, E.A., Gosudarstvennyye preobrazovaniya sistemy zhenskogo professional'nogo obrazovyaniya v kontse $19-$ nachale $20 v$. [State transformations of the system of female vocational education in the late 19 - early 20 centuries], in print.

12. Lobova, V.V., Vyssheye zhenskoye obrazovaniye na Donu v pervoy chetverti XX v. [Higher female education on the Don in the first quarter of the 20th century], in Vestnik SPbGU, ser. 2, 2012, no. 4.

13. Markowski, A., The Tsarist University, university and society 1869-1917, in History of the University of Warsaw 1816-1915, Monumenta universitatis varsoviensis 1816-2016, Warsaw, 2016.

14. Miaso, J., Commercial education in the Kingdom of Poland (1855-1914), in Tracts from the History of Education, no. 8, 1965.

15. Miaso, J., Secret teaching in the Kingdom of Poland in the light of the documents of the Russian authorities, in Tracts from the History of Education, no. 33, 1990.

16. Orzeszkowa, E., About a Woman, Warsaw, 1873. 
17. Prywatne Wyższe Kursy Żeńskie w Warszawie [Private Higher Female Courses in Warsaw], URL: szukajwarchiwach.pl/72/228/0/?q=wy $\% \mathrm{C} 5 \% \mathrm{BCsze}+$ kursy $+\% \mathrm{C} 5 \%$ BCe $\%$ C5\%84skie\&wynik=13\&rpp=15\&page=1\#tabZespol.

18. State Archive in Warsaw (Milanówek branch): Class schedule, semester II, in Private Higher Female Courses in Warsaw, Team 72/228/12.

19. State Archive in Warsaw (Milanówek branch): Program of courses: Private Higher Female Courses in Warsaw, Team (No. 72/228/12).

20. State Archive in Warsaw (Milanówek branch): The Tsarist University of Warsaw, Team (No. 72/214/663-664).

21. Stawiak-Ososińska, M., Outline of the Warsaw Midwives School (1862-1906), in Pedagogical Studies of the Świętokrzyska Academy, no. 15, Kielce, 2005.

22. Zigel Fedor Fedorovich, in Slavyanstvo. Forum slavyanskikh kul'tur [Slavs. Forum of Slavic cultures], URL: sklaviny.ru/biograf/bio_z/zigelfefe.php.

DOI: https://doi.org/10.31119/phlog.2018.3.6 